Pakistan Journal of Humanities and Social Sciences
Volume 8, Number 2, 2020, Pages 47 - 56

\title{
Macroeconomic and Socioeconomic Determinants of Economic Growth: An Empirical Examination of South Asian Economies
}

\author{
Hina Ali $^{1}$, Khizra Sardar ${ }^{2}$ \\ ${ }^{1}$ Assistant Professor, Department of Economics, The Women University Multan, Pakistan \\ 2 M.Phil Scholar, Department of Economics, The Women University Multan, Pakistan
}

\begin{tabular}{|c|c|}
\hline ARTICLE INFO & ABSTRACT \\
\hline $\begin{array}{ll}\text { Article History: } & \\
\text { Received: } & \text { July 21, } 2020 \\
\text { Revised: } & \text { Dec 17, } 2020 \\
\text { Accepted: } & \text { Dec 23, } 2020 \\
\text { Available Online: } & \text { Dec 31, } 2020\end{array}$ & \multirow{3}{*}{$\begin{array}{l}\text { Economic growth is not a new phenomenon; empiric is filled with } \\
\text { studies from the preceding two centuries that examined growth. } \\
\text { The new thing in this analysis is that this study considers growth } \\
\text { determinants for south Asian economies. The reason behind this } \\
\text { selection is that most of the studies didn't consider a combined } \\
\text { analysis of these states. In this regard, this paper has examined } \\
\text { seven explanatory variables that are unemployment, Access to } \\
\text { electricity, domestic credit to the private sector, foreign direct } \\
\text { investment, inflation, and total debt while gross domestic product } \\
\text { as a dependent variable has been examined. To prove these } \\
\text { determinants' role statistically PMG/ARDL (Pooled Mean Group } \\
\text { Auto-Regressive Distributed Lagged Model) test has been utilized. } \\
\text { Estimates provoked a statistically significant role of these } \\
\text { determinates in economic growth determination. }\end{array}$} \\
\hline $\begin{array}{l}\text { Keywords: } \\
\text { Unemployment Rate, Domestic } \\
\text { Credit to Private Sector, Foreign } \\
\text { Direct Investment, Population } \\
\text { Growth Rate }\end{array}$ & \\
\hline & \\
\hline
\end{tabular}

(C) 2020 The Authors, Published by iRASD. This is an Open Access Article under the Creative Common Attribution Non-Commercial 4.0

Corresponding Author's Email: hinaali@wum.edu.pk

\section{Introduction}

Whenever we examine any phenomenon the first question arises about the conception of that phenomenon. Some economists ranked the growth of an economy and development as an identical perception. But there exists a clear and prominent variation that might be clear through subsequent perception, growth of an economy epitomizes addition in the value of commodities and services of an entity due to improved productivity (proficiency) of factors of production. Although the process by which an economy revises (amend) the political, social, and economic wellbeing of its inhabitants, identified as economic development.

Following the International Monetary Fund (IMF) report 2012, GDP growth is the instrumentation in inflation attuned activities and value of commodities and services elevated by an economical mechanism over the time series. The economic growth of an economy is typically approximated as the fraction of amplification in real GDP rate or it may be approximated by the incremented value of the gross domestic product (GDP). From the preceding two decades, several empiric and reviewed studies have endeavored to recognize and clarify the growth determinants in an entity.

This isn't to say that theories about growth have no usage and importance for the determination of growth components. But the matter is the dissimilarity in existing researches about theories of growth that's classically companionable with each other. As of an empirical assessment, the subject matter mostly researches faces are identified as the uncertainty of model which appears as the theory doesn't offer an adequate guideline to choose the suitable model for determination of growth. According to an estimate of more than one hundred and forty (140) determinants of growth have been identified by researches donned earlier.

Regardless of the enormous volume of empiric studies engendered by new theories of growth, there's curiously little accord about which approach is utmost striking in the 
amplification of cross country dissimilarities about growth determinants. This research has been premeditated to present significant evidence about the determinants of aggregate growth and the fundamental components of growth. This study considers all necessary spheres about growth such as social, macro-economic, demographic, institutional setting, the openness of the economy has been examined here.

All economies examined in this research are developing economies and by regional classification known as south Asian Counties. South Asia comprises eight countries that are Pakistan, India, Bangladesh, Bhutan, Afghanistan, Maldives, Siri Lanka, and Iran. The reason for the selection of these economies and the main purpose to conduct this research is that all literary studies have mainly focused on the determination of economic growth in developed economies. Some studies also examined determinants of economic growth for south Asian economies but these studies examine only individual states. So, the purpose of this research is to examine growth determinants in South Asian countries combined.

The first segment of this study formalizes an introduction about conception and determinants of growth. In the second segment review of some empiric studies has been documented in the third, theoretical formation while in the fourth segment an estimation about growth determinates has been exhibited. In the end, concluded remarks are displayed. The objectives are (i) Identify growth components for developing economies especially for South Asia, (ii) Consider all relevant spheres for the determination of economic growth such as social, economic, macro-economic and institutional, etc., (iii) Identify the variant role of these components in different Economies and (iv) Check the significance and relationship level (strong, weak) of exogenous factors with endogenous variables.

\section{Literature Review}

Nicolas Belorgey et al., (2006) examined a panel data analysis about per-person productivity (GDP over employment) amid different states. Data had been gathered from the OECD database, WDI, and WITSA (World Information Technology service Alliance) for 25 countries. Despite this, the OLS generalized method of movements (GMM) had been examined as an estimated tool. Market size, labor market, macroeconomic variables, research \& development expenditures, public infrastructure, human capital, financial depth, and employment protection were the main examined variables of this study. Findings concluded that price stability, information \& communication technology, and financial sector depth had exhibited significant association while employment rate exhibited a negative but significant correlation with productivity.

Steven N. Durlauf et al., (2008) documented about either growth theories are robust or not. According to them there exist correct growth model uncertainty, but utilizing model averaging methods estimates provoked that fundamental growth theories can efficiently illustrate the aggregate growth conception. In this analysis for 53 states data collected from 1965-74, for 54 states from 1975-84 and 57 states from 1985-94; so basically, this analysis covered an unbalanced panel analysis. Examined variables were capital accumulation, human capital, government consumption level, and macroeconomic stability. The study failed to found some strong evidence that any growth theory is robust or not. However, the role of the institutions and religion may significantly influence growth.

Joanna W. D (2009) highlighted the role of migration in economic growth (convergence) for European markets. For this analysis, the researcher gathered data from OECD for 27 European countries for the variables GDP per capita, investment, school enrollment, education expenditure, research \& development expenses, and net migration rate; for the period of 1990-2007. The researcher examined the role of migration in two ways; the researcher examined the role of migration role in convergence and also checked its impact on economic growth. Regression estimates provoked that migration significantly influenced the convergence coefficient.

Enrique Moral Benito (2010) elaborated on the economic growth determinants via examining the Bayesian Panel data technique. Data for 35 variables of the study were gathered for the period 1960-2000. The main components of the analysis were external or macroeconomic environment, institutions or governance, fixed factors, and geography. Despite 
the SDM-FLS panel approach researcher utilized the sensitivity analysis tool, to check the robust determinants of economic growth. Findings provoked that fundamental determinants of economic growth were prices of investment commodities, political rights, and distance amid major global regions or cities.

Enrique Moral Benito (2010) detailed an essay about growth econometrics. Fundamental variables of this analysis were GDP, education, population growth, investment, trade openness, life expectancy. Barro regression and Monte Carlo estimates signified that population, life expectancy, and investment rate presence in any model may lead towards the goodness of fit or better results. Moreover, endogeneity and uncertainty influence the empirical estimates of growth analysis. In the end, it was concluded that the investment rate is the primal one component in growth determination.

Ryszard Rapacki and Mariuz Prochinak (2013) highlighted the growth paths within Central and Eastern European (CEE) states especially emerging economies. This study considered 29 emerging States throughout 1993-2007. Gross fixed capital formation, school enrollment, exports, economic freedom were the independent variables while GDP per capita was examined as a dependent variable. Here, two main ways were considered to examine the growth path that was growth accounting convergence and income level convergence. Approximations of the regression analysis assured that increased factor productivity leads to a high growth level.

Usha Nair and Diana (2001) illustrated the association of FDI with economic growth for developing states. Mixed Fixed \& Random model (MFR) has been testified for 24 developing regions for the period of 1971 to 1995 form the world development indicator (WDI). Human capital, gross domestic investment, FDI, inflation, school enrollment of adult's causality via examining Granger causality has been examined in this analysis. the outcome attained from this study was that FDI, trade openness, human capital are robust to the economic growth of an economy especially for developing economies.

Dr. Gaurav (2011) elaborated some key determinants of economic growth and FDI for the case of BRIC's economies via the in taking panel data approach. The random-effect model for BRIC's economies for the period 1975-2009 has been examined. Empirical estimates affirmed that market size, infrastructure development, gross capital formation have robust while macroeconomic stability has a less strong effect on the economic growth of BRIC's economies. Moreover, this paper highlighted that India and China were the most promising or rising States among the BRIC countries.

Narayana murthy et al., (2010) affiliated economic growth and FDI for BRIC's counties. This study covered the era for the period of 1975 to 2007 for the variables; Size of market, FDI inflow, inflation, total trade, industrial production from WDI. Fixed Effect (FE) and Random Effect (RE) model findings of the analysis concluded the significant role of the variable in provoking economic growth and in the determination of FDI inflows. Aviral Tiwari and Mihai Mutascu (2010) documented economic growth in the case of Asia via considering a panel data analysis. The data for this study encompasses the period of 1986-2008. The primal components highlighted in this analysis were export and FDI.

Khalid Ahmed and Wei Long (2012) documented economic growth with environmental components. Environmental Kuznets Curve was conceptualized to examine economic growth affiliation with $\mathrm{CO} 2$, energy consumption level, liberalization of trade, and role of the population for the economy of Pakistan for the period of 1971-2008. The Co-integration technique via considering the ARDL bound testing approach has been examined in this research. Both for short and long-run estimates affirmed significant association amid the examined variables of this study. In the end, the stability of variables and their cointegration significance are also assessed in this document.

Rahman, M. M., Rana, R. H., \& Barua, S. (2019) explored economic growth drivers by using GMM for South Asian economies. Time series data over the time 1975-2016 has been examined for the case of South Asia. Both dynamic and static estimates disclosed that gross capital formation, remittance, and energy use were the main economic growth drivers. 
Although a foreign direct investment, trade, and govt. expenditures didn't confirm the significant effect.

Aladejare, S. A. (2020) compared 'macroeconomics' and 'resource' determinants of growth for selected regions (COMESA and ECOWAS) of Africa. The pool means group estimation approach was examined that highlighted that in the common market for Eastern \& Southern Africa (COMESA) macroeconomic determinants effect is larger than resource determinants while in case of the economic community of West African States (ECOWAS) resource determinants confirmed much stronger effect rather than macroeconomic factors.

\section{Theoretical Review}

Literature is filled with variant theories about growth and it's determined. In this study, we may only consider the studies that attained robust significance by researchers. In this regard, the principal theories about growth were exhibited in the subsequent paragraph. Firstly, we consider the Mercantilist view that considered the growth of an entity in the form of incremented wealth and assets and by increased export volume. In their opinion higher the accumulated gold, silver, and running a surplus of trade in an economy higher the level of growth of that entity.

Classical economists (Adam Smith and his followers) initiated that specialization in productive capacity and the role of increasing returns to scale (economies of scale) stimulate growth in an economy. Smith (1776) "wealth of nations" highlighted the role of market forces in determining demand, supply, and productivity in an economy. Smith claimed that growth (income per capita) is determined by skills, judgment with which labor is employed, and dexterity in an economy.

While according to the Neo-classical conception growth of an economy was grounded on supply-side components for instance; productivity of labor, workforce or labor force size, inputs, the supply of goods, role of technology, and many others. Endogenous theories of growth initiated that human capital accumulation and technological innovation rate determines the growth rate. The Neo-classical viewpoint about the growth of an economy was that increased human-capital (or labor) lead towards diminishing returns to scale.

In their opinion increased human-capital had only an impermanent and imperfect influence on the growth level of an economy. To an extent, high capital accumulation in an economy leads towards the high growth (steady-state level) rate but after that extent as accumulated capital grows in that economy, growth may tend to diminish. On the other hand, Keynes provoked the demand-side factors in the determination of economic growth. According to this approach, aggregate demand performs a significant role in the manipulation of economic growth in the short-run and also in the medium run.

However utmost theories about growth disregard aggregate demand role, some argued that recession may basis for hysteresis effect on the economic growth of the long run. Confines to growth theories, from other points of view such as from environmental viewpoint, some studies argued that in the long-run growth of an economy might be controlled by global warming and degradation of the natural resource. And if we may consider Malthus theory then demographical components like population pressure may influence or determine the economic growth in an economy.

\section{The Methodology of the Study}

The methodology of this research encompasses six sections. That detailed down in the following sub-chapters one by one. Firstly econometrical model estimation has been documented. After that data source, and then stationarity of the data set is exhibited. Despite this descriptive and correlation analysis along with PMG/ARDL model (short run and long run), estimates have been documented. To examine the role of sleeted variables on economic growth determination, the following econometrical model has been initiated in this study.

$$
\text { GDP.Gt }=\beta_{0}+\beta_{1} \text { UNMPt }_{t}+\beta_{2} \text { A.LCTt }+\beta_{3} \text { DCPS }_{t}+\beta_{4} \text { FDI }_{t}+\beta_{5} \text { INFt }_{t}+\beta_{6} \text { POPt }_{t}+\beta_{7} \text { T.DBT }_{t}+e_{t}
$$


Where, GDP. Get = Gross Domestic Product Growth, UNMPt = Unemployment rate, A.ELCTt $=$ Access to electricity, DCPSt $=$ Domestic Credit to Private Sector, FDIt $=$ Foreign Direct Investment, INFt $=$ Inflation, interest rate, POPt $=$ Population growth rate, T.DBTt = Total Debt and et $=$ error Term.

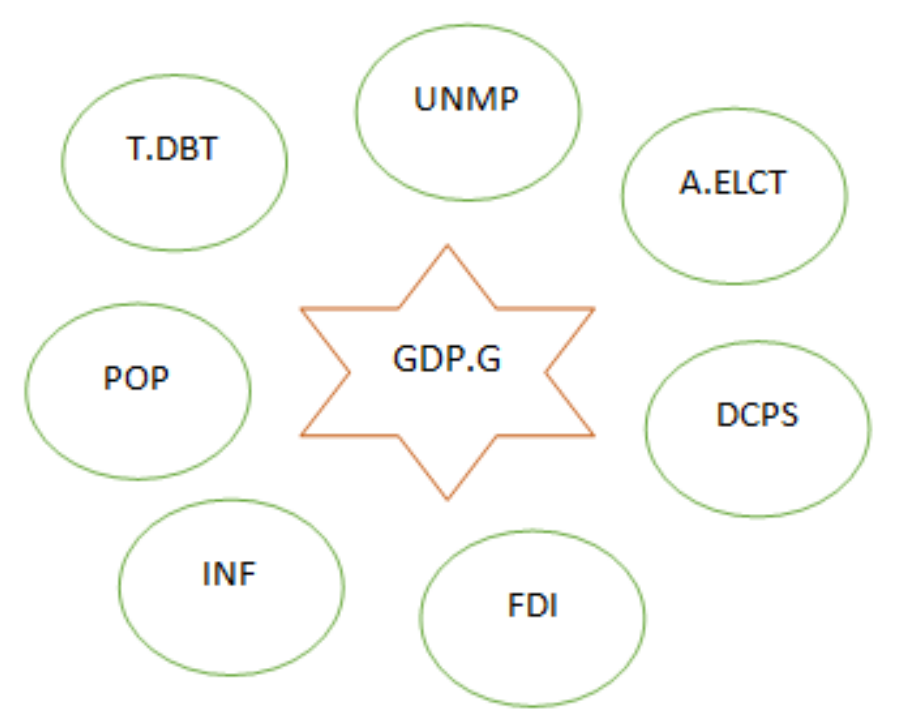

Figure 1: Examined variables Description

To collect data for this analysis data has been collected from world development indicator online source 2019 for south Asian countries for the time series of 2006 to 2017. Due to the unavailability of data for some variables, researchers can't gather data for 2018 so that's why data encompasses only from 2006 to 2017. unit of measure selected for variables of the study is the percentage. From each sphere or family researcher picked two members except the social and demographic sphere.

\section{Results}

\subsection{Descriptive Statistic}

Usually, descriptive statistics have been taken into account to specify the basic and primal characteristics of the data set. A descriptive statistic is a way or tool to express our data set briefly and concisely. So, that reader via just at one glance may understand the basic information about the data set. Mainly a descriptive statistical table exhibits mean value, range, deviation range, degree of peaks (kurtosis), normality of distribution, and also a standard deviation from the mean value of the data set.

Table 1: Descriptive Statistics Estimation

\begin{tabular}{ccccccccc}
\hline & GDP.G & UNMP & A.ELCT & DCPS & FDI & INF & POP & T.DBT \\
\hline Mean & 5.5185 & 4.2637 & 78.1336 & 34.9580 & 2.1446 & 8.3503 & 1.8440 & 2.6482 \\
Median & 5.7454 & 4.1160 & 83.8504 & 35.8724 & 1.1260 & 7.2743 & 1.4904 & 2.0064 \\
Maximum & 14.3624 & 8.8640 & 100.0000 & 59.1784 & 15.2659 & 22.7992 & 4.1929 & 8.2009 \\
Minimum & -7.2288 & 0.6500 & 42.7000 & 3.9410 & -0.0735 & 0.5669 & 0.5399 & 0.0580 \\
Std. Dev. & 3.4116 & 1.9952 & 17.5185 & 14.7554 & 2.9801 & 5.1272 & 1.0300 & 2.0535 \\
Skewness & -0.5298 & 0.5718 & -0.5306 & -0.6349 & 2.5049 & 1.0922 & 0.9216 & 0.7652 \\
Kurtosis & 6.1746 & 3.2006 & 1.9616 & 2.7914 & 9.6648 & 3.6927 & 2.8707 & 2.7107 \\
Jarque-Bera & 22.8692 & 2.7523 & 4.5008 & 3.3813 & 141.9366 & 10.7232 & 6.9709 & 4.9537 \\
Probability & 0.0000 & 0.2525 & 0.1053 & 0.1843 & 0.0000 & 0.0046 & 0.0306 & 0.0840 \\
$\quad$ Sum & 270.4089 & 208.925 & 3828.549 & 1712.944 & 105.0866 & 409.1650 & 90.3600 & 129.763 \\
$\quad$ Sum & 558.7030 & 191.084 & 14731.24 & 10451.14 & 426.3007 & 1261.851 & 50.9271 & 202.412 \\
Sq. Dev. & 49 & 49 & 49 & 49 & 49 & 49 & 49 & 49 \\
Observations & 49 & & & & & &
\end{tabular}

The above-exhibited table highlighted the chief features of the examined data set. Such as via considering mean, median and mode values one can understand the average range of the data set. While on the other hand, maximum and minimum values not only highlights 51 
small one and large one figure of data set but also tells us about the total range of the data set examined in the study. Values of standard deviation highlight the fact or units about how much data may deviate from its actual mean value. If the value of standard deviation is high that shows the high deviation of observation from mean and also shows that there are high chances of biasness in that data set. Estimated values of skewness show that GDP.G, A.ELCT, DCPS are negatively skewed while on the other hand UNMP, FDI, INF, POP, T.DBT are positively skewed. Moreover, kurtosis data shows the degree of weakness or flatness in the data set. So here, GDP.G, UNMP, FDI, and INF are leptokurtic while A.ELCT, DCPS, and POP are platy-kurtic. At the end probability values, the sum of total data, and observed years (values) are displayed.

\subsection{Correlation Matrix}

To inspect the nature of the relationship among the examined variables correlation matrix has been examined. The correlation matrix demonstrates that either there's a positive correlation or negative correlation among the examined variables. A correlation matrix illustrates the correlation of a variable with itself and also with other variables of the study. A variable always has a perfect correlation (equals 1 ) with itself while with other variables it ranges from 0 to 1 . The below-displayed table represents the conception or may help the reader to understand the concept of correlation.

Table 2: Correlation Matrix Estimation

\begin{tabular}{|c|c|c|c|c|c|c|c|c|}
\hline & GDP.G & UNMP & A.ELCT & DCPS & FDI & INF & POP & T.DBT \\
\hline GDP.G & 1 & & & & & & & \\
\hline UNMP & 0.0708 & 1 & & & & & & \\
\hline A.ELCT & -0.1447 & -0.0903 & 1 & & & & & \\
\hline DCPS & 0.0061 & -0.6690 & 0.2390 & 1 & & & & \\
\hline FDI & 0.1148 & 0.0719 & 0.4494 & 0.2784 & 1 & & & \\
\hline INF & -0.1750 & -0.1519 & 0.0053 & 0.0085 & 0.0779 & 1 & & \\
\hline POP & -0.0115 & 0.6569 & 0.0094 & -0.5735 & 0.2914 & -0.0545 & 1 & \\
\hline T.DBT & 0.0306 & -0.3149 & 0.5739 & 0.4438 & 0.2479 & -0.2120 & -0.2345 & 1 \\
\hline
\end{tabular}

Author's Estimates via Employing Eviews (9) Software

In the above-displayed table correlation among the examined variables of this study has been illustrated. In the first row and Colum GDP. G correlation with other variables has been exhibited. GDP. G has been affirmed positive correlation with UNMP, FDI, DCPS, and T.DBT and negative correlation of GDP.G has been affirmed with A.ECLT, INF, and POP. Moreover, GDP.G has also affirmed a perfect correlation with itself as diagonal number 1 exhibits. UNMP has affirmed a positive correlation with all variables except A.ECLT, DCPS, and INF. While A.EELCT shows a negative association with GDP.G and UNMP but a positive correlation is shown with the remaining ones. Except for UNMP, all variables have affirmed a positive correlation with DCPS. Furthermore, FDI exhibits a positive correlation with all variables of this analysis. INF shows a negative correlation with all except A.ELLCT, DCPS, and FDI. POP shows a positive correlation with A.ELCT, UNMP, and FDI and also shows a negative correlation with others. IN the end, T.DBT confirmed a negative correlation with UNMP, INF, and POP. However, a positive correlation with the other remaining variables has also been confirmed by T.DBT.

\subsection{Stationarity of the Data Set}

Stationarity tests usually examine to check either there's any kind of trend in the data set or not. In other words, the stationarity test tells us about the unit root hold true or not in the case of examining data. A data set is said to be stationary if it means value plus variance value and covariance values are equal to zero. In today's modern society several tests are examined to check the stationarity of the data set. So, to check the stationarity this paper also examined some stationarity tests for panel data analysis. Here, five tests are examined. As in the below-exhibited table Levin, Lin \& Chu t*; Breitung t-test; Im, Pearson and Shin W-stat; ADF - Fisher Chi-Square; and PP-Fisher Chi-square tests are examined. 
Table 3: Stationarity Tests Estimation

\begin{tabular}{lllllll}
\hline Variables & $\begin{array}{l}\text { Levin, Lin } \\
\text { \& Chu t* }\end{array}$ & $\begin{array}{l}\text { Breitung } \\
\text { stat }\end{array}$ & $\begin{array}{l}\text { Im, } \\
\text { Pesaran } \\
\text { and Shin } \\
\text { W-stat }\end{array}$ & $\begin{array}{l}\text { ADF } \\
\text { Fisher Chi- } \\
\text { square }\end{array}$ & $\begin{array}{l}\text { PP - Fisher } \\
\text { Chi-square }\end{array}$ & Rank \\
\hline GDP & $-6.1614^{*}$ & $-1.5975^{*}$ & $5.7947^{*}$ & $59.4115^{*}$ & $73.1766^{*}$ & $\mathrm{I}(0)$ \\
A.ELCT & $-1.7379^{*}$ & $-1.8834^{*}$ & $1.7684^{*}$ & $7.7462^{*}$ & $15.6900^{*}$ & $\mathrm{I}(0)$ \\
DCPS & $-12.9804^{*}$ & $-2.1470^{*}$ & $-3.1405^{*}$ & $39.2293^{*}$ & $49.4204^{*}$ & $\mathrm{I}(1)$ \\
FDI & $-4.6518^{*}$ & $-0.9931^{* *}$ & $-1.4495^{*}$ & $25.5573^{*}$ & $44.5009^{*}$ & $\mathrm{I}(0)$ \\
UNMP & $-6.3290^{*}$ & $-2.0220^{*}$ & $-1.1003^{*}$ & $27.5537^{*}$ & $86.6762 *$ & $\mathrm{I}(1)$ \\
T.DBT & $-3.3356^{*}$ & $-1.1452^{*}$ & $-2.7899^{*}$ & $36.3791^{*}$ & $83.3432^{*}$ & $\mathrm{I}(1)$ \\
POP & -31.4328 & $-0.1536^{*}$ & $-22.3247^{*}$ & $123.068^{*}$ & $18.6959^{*}$ & $\mathrm{I}(0)$ \\
INF & $-3.7531^{*}$ & $-1.7537^{*}$ & $-1.3980^{*}$ & $24.2861^{*}$ & $51.0446 *$ & $\mathrm{I}(0)$ \\
\hline
\end{tabular}

Author's Estimates Via Employing Eviews (9) Software

In the above-grounded table, the stationarity of the variables through the examination of different statistical tests has been examined. If any of the Colum (test) exhibits two stars then this demonstrates that the examined variable is nonstationary by that test but it does not mean that, that variable is nonstationary. But it means that the variable is non-stationary only by one test. Such as A.ELCT shows itself as non-stationary in accordance to the $1 \mathrm{~m}$, Pearson and Shin W-stat; ADF - Fisher Chi-Square; and PP-Fisher Chi-square tests. All variables are stationary but with different ranks. Such as GDP. G, A.ELCT, FDI, POP, INF are stationary at level "I (0)" while UNMP, T.DBT, DCPS are stationary at 1st difference "I (0)". In short, we can conclude that all variables of this study are statistically stationary and there exists no unit root in the data set. And there's no trend in the examined variables.

\subsection{PMG/ARDL: Pooled Mean Group Auto Regressive Distributed Lag Model}

The polled mean group (PMG) estimation allows intercepts, short-run parameters, and cointegration terms to differ autonomously across different cross-sections. Although, it constrains long-run parameters to remain constant. PMG/ARDL is acceptable for this research because of its versatility and flexibility. However, it is bound for cross-sectional variations in the short-run (speed of adjustment) resulting from heterogeneous characteristics of crosssections (Pesaran et al., 1999). The stationarity estimates show the cointegration of both ranks (Io and I1). So, due to this mixed combination researcher examined the Pooled Mean Group Auto-Regressive Distributed Lagged Model (PMG/ARDL). ARDL model is the model that takes the lag of both variables (dependent and independent variable). Following is the description of long-run estimates following the PMG/ARDL model.

Table 4: Short Run Estimation

\begin{tabular}{ccccc}
\hline \multicolumn{5}{c}{ Short Run Cointegrating form } \\
\hline Variable & Coefficient & Std.Error & t-static & Prob. \\
\hline D(GDP.G (-1)) & 0.3870 & 0.1412 & 2.7397 & 0.0088 \\
D(UNMP) & -6.3365 & 2.2140 & -2.8620 & 0.0060 \\
D(A.ELCT) & -0.4297 & 0.3629 & -1.1841 & 0.2427 \\
D(DCPS) & 0.4191 & 0.3177 & 1.3192 & 0.1939 \\
D(FDI) & 0.0416 & 0.9047 & 0.0460 & 0.9635 \\
D(INF) & 0.0285 & 0.1331 & 0.2145 & 0.8307 \\
D(POP) & -24.8680 & 10.4116 & -2.3884 & 0.0196 \\
D(T.DBT) & -5.1063 & 4.4349 & -1.1513 & 0.2535 \\
COINT-EQ1 & -0.7453 & 0.1969 & -3.7852 & 0.0003 \\
\hline
\end{tabular}

Author's Estimates via Employing Eviews (9) Software

The preceding exhibited table represents the short-run estimates for the analysis of this study. In short-run most of the variables affirmed insignificant affiliation but some variables also affirmed statistically significant cointegration. The primal and significant factor of this table is the estimates of "COINTEQ (1)" because the accuracy of long term estimates or foundation of long-run cointegration depends on this value. If that value is lower than one (1) and also approved itself as statistically significant then there exists long term affiliation among the examined variables. 
The preceding table fulfilled both requirements. So, now we can state that in our variables (in our model) there exists long term affiliation and cointegration. One year preceding the Lagged value of GDP.G shows positive and statistically significant affiliation in the short run. Moreover, UNMP also affirmed long term and statistically significant cointegration with economic growth (GDP.G). Furthermore, the population also affirmed a statistically significant cointegration in the short-run table.

Table 5: Long Run Estimation

\begin{tabular}{cccrr}
\hline \multicolumn{5}{c}{ Long Run Coefficients } \\
\hline Variable & Coefficient & Std.Error & t-Statistic & Prob. \\
\hline UNMP & 1.0510 & 0.1328 & 7.9087 & 0.0000 \\
A.ELCT & 0.0725 & 0.0085 & 8.4495 & 0.0000 \\
DCPS & 0.1270 & 0.0052 & 24.0086 & 0.0000 \\
FDI & 0.8690 & 0.0831 & 10.4489 & 0.0000 \\
INF & -0.3964 & 0.1582 & -2.5046 & 0.0146 \\
POP & 1.9544 & 0.2647 & 7.3834 & 0.0000 \\
T.DBT & 0.7487 & 0.2632 & 2.8443 & 0.0058 \\
\hline
\end{tabular}

Author's Estimates via Employing Eviews (9) Software

The chief part of this analysis is the long-run analysis table. This table depicts the role of independent variables in the determination of growth for south Asian economies. All variables depict a statistically significant role in the determination of GDP growth or economic growth. All economies examined in this research are developing economies and by regional classification known as south Asian Counties. The reason for the selection of these economies and the main purpose to conduct this research is to study growth determinants especially for developing states like South Asian countries. So, the purpose of this research is to examine growth determinants in South Asian countries combined.

Unemployment (UNMP) plays a vital and significant role in the determination of the economic growth of South Asia. For south Asian economies unemployment has affirmed positive affiliation with economic growth. Following theories unemployment usually have a negative relationship with growth but this analysis shows positive estimates. The reason behind this phenomenon is that all states (south Asian) economies are developing economies. And most of the developing economies rely heavily on the Agricultural sector (such as Pakistan and India) where's disguised unemployment is quietly common. So, that's why here unemployment shows a positive association with economic growth. Due to unemployment, there is a "1.051030" percent change in economic growth.

Access to electricity (A.ELCT) performs a statistically significant role in GDP growth determination. Due to changes in access to electricity to the masses, there's a "0.072530" percent change in economic growth. The change (association) is minor but this change (association) is significant. When masses of an economy have increased access to electricity than their working capability or production increases. Because to start manufacturing products or any machine electricity requires and in today's modern time despite machinery electricity becomes a vital part of an individual's life. Most of the functions or day to day work are now depend on electricity's availability.

Domestic credit availability to the Private sector (DCPS) is another one variable that significantly determines the growth of south Asian economies. A change in domestic credit availability to the Private sector causes a "0.127082" percent change in economic growth. The change in economic growth is positive because as credit availability to the private sector (or to any sector) increases in an economy it leads towards more economic (production) activities such as investment increases, employment opportunities expanded, the income of the masses increases that in turn have a positive and significant influence on economic growth. As like our estimates for South Asian countries provoked that fact.

Foreign direct investment also affirmed positive cointegration with economic growth for the case of South Asian economies. Due to foreign direct investment, there's a "0.869073" percent amendment in GDP growth (economic growth). Interconnections with foreign economies or FDI not only increase GDP growth. But it also assist economies in development, 
in technology transfer, people now have more range and open access to goods, the competition also increases due to this domestic firms also groom up themselves to compete foreign marketers. In Short, FDI either in the form of inflow or outflow leads an economy towards high and sustained economic growth.

However, the inflation rate (INF) signifies a negative correlation with economic growth as like as theories predicted that an increase in inflationary rate or an increase in goods prices has/ had a negative connection with economic growth. Due to this conception change in inflation rate about one Percent have affirmed "-0.396448" percent change in economic growth and that change kind is negative for South Asian counties. Whenever there's a sustained and persistent increase in commodities prices there's also a decline in goods demand that influences supply and then the production of goods that in turn harm economic growth.

Population growth (POP) long-term estimates provoked that as like other independent variables population growth also shows statistically significant collaboration with economic growth of South Asian states. One percent change in population growth causes a "1.954468" percent change in economic growth. The nature of this change is positive and much strong than other variables of this analysis. Population or human capital performs a significant role in the development and economic growth. and many empirical studies provoked this conception. Because to start a business or to run a machine and to provide a service all works require men (human capital). Due to this logical conception population growth has affirmed positive affiliation with economic growth.

Total debt (T.DBT) has statistically significant cointegration with economic growth and our long-term estimates provoked it. Due to debt, there's a "0.748732" percent change in economic growth. However, in theories, we have studied the negative effect of od debt on economies because debt is like a burden. But here, that's not the case the reason for this positive cointegration is that if the debt is utilized efficiently in an economy for development purposes or the wellbeing of its masses then the debt may not remain like a burden but then it may become like a blessing. So, the need is to utilize it efficiently. South Asian economies confirmed positive affiliation because most of these economies via utilizing debt or foreign aid initiated a step further towards growth.

\section{Conclusion}

This study examined the case of South Asian countries and studied their primal or key determinates of growth. In this respect, this study considered seven explanatory variables that are unemployment, Access to electricity, domestic credit to the private sector, foreign direct investment, inflation, and total debt, and one dependent variable GDP growth. To prove these determinants' role statistically PMG/ARDL (Pooled Mean Group Auto-Regressive Distributed Lagged Model) has been employed. Estimates of the analysis provoked a statistically significant role of these determinates in economic growth determination. In the long run except for inflation (INF), all variables affirmed affirmative cointegration with economic growth for the case of South Asian economies.

\section{Reference}

Ahmed, K., \& Long, W. (2012). Environmental Kuznets curve and Pakistan: an empirical analysis. Procedia Economics and Finance, 1, 4-13.

Aladejare, S. A. (2020). Macroeconomic Vs. Resource Determinants of Economic Growth in Africa: A COMESA and ECOWAS Study. International Economic Journal, 34(1), 100-124.

Bank (2012). "The World Development Indicators 2012", CD-ROM Version. Washington: The World Bank, www.unctad.org/.

Belorgey, N., Lecat, R., \& Maury, T. P. (2006). Determinants of productivity per employee: An empirical estimation using panel data. Economics Letters, 91(2), 153-157.

Ciccone, A., \& Jarociński, M. (2010). Determinants of economic growth: will data tell?. American Economic Journal: Macroeconomics, 2(4), 222-46.

Durlauf, S. N., Kourtellos, A., \& Tan, C. M. (2008). Are any growth theories robust?. The Economic Journal, 118(527), 329-346.

Giudici, E., \& Mollick, A. V. (2008). Convergence in the eastern Caribbean states. The Annals of Regional Science, 42(4), 893-909. http://ssrn.com/abstract=525882.

International Money Fund (2012). "International Money fund Report 2012". Moral-Benito, E. (2010). Essays on growth econometrics. 
Nair- Reichert, U., \& Weinhold, D. (2001). Causality tests for cross- country panels: a New look at FDI and economic growth in developing countries. Oxford bulletin of economics and statistics, 63(2), 153-171.

Pesaran, M. H., Shin, Y., \& Smith, R. (1999). Pooled mean group estimation of dynamic heterogeneous panels. Journal of the American Statistical Association, 94, 621-634.

Rahman, M. M., Rana, R. H., \& Barua, S. (2019). The drivers of economic growth in South Asia: evidence from a dynamic system GMM approach. Journal of Economic Studies.

Ranjan, V., \& Agrawal, G. (2011). FDI inflow determinants in BRIC countries: a panel data analysis. International Business Research, 4(4), 255.

Rapacki, R., \& Próchniak, M. (2013). Economic growth paths in the CEE countries and selected emerging economies, 1993-2007. Research in economics and business: Central and Eastern Europe, 2(1).

Tiwari, A. K., \& Mutascu, M. (2011). Economic growth and FDI in Asia: A panel-data approach. Economic analysis and policy, 41(2), 173-187.

Vijayakumar, N., Sridharan, P., \& Rao, K. C. S. (2010). Determinants of FDI in BRICS Countries: A panel analysis. International Journal of Business Science \& Applied Management (IJBSAM), 5(3), 1-13.

Wolszczak-Derlacz, J. (2009). Does migration lead to economic convergence in an enlarged European market? Bank I Kredyt, 40(4), 73-90. 